05

\title{
Разработка и исследование двуслойного металлокерамического материала для защитных преград в условиях высокоскоростного удара
}

\author{
() А.Н. Ищенко, А.Н. Табаченко, Р.Н. Акиншин, С.А. Афранасьева, И.Л. Борисенков, Н.Н. Белов, \\ В.В. Буркин, А.Б. Скосырский, М.В. Хабибуллин, А.В. Чупашев, Н.Т. Югов
}

Научно-исследовательский институт прикладной математики и механики Национального исследовательского Томского государственного университета, 634050 Томск, Россия

ฯ e-mail: s.a.afanasyeva@mail.ru

(Поступило в Редакцию 14 ноября 2017 г.)

Рассмотрена возможность повышения физико-механических характеристик композиционных материалов для защитных конструкций от высокоскоростного удара. Путем самораспространяющегося высокотемпературного синтеза получен двуслойный металлокерамический материал: лицевой слой - металлокерамика на основе диборида титана со связкой из никелида титана, тыльный слой - титановый сплав. Исследование расчетно-экспериментальным методом противоударной стойкости данного композита в сравнении с однородной титановой пластиной показало качественное преимущество, выраженное в отсутствии ударного кратера в металлокерамической пластине после соударения со стальным сферическим ударником и более сильной деформацией и предразрушением последнего. Двуслойный металлокерамический материал оказывает большое сопротивление прониканию стального ударника.

DOI: $10.21883 /$ JTF.2018.07.46170.2556

\section{Введение}

Дальнейшая модернизация защитных преград от высокоскоростных осколочных элементов путем применения однородных металлических или керамических конструкций себя исчерпала: металлические пластины тяжелые, керамические материалы являются хрупкими и ненадежными, и те и другие не выдерживают интенсивных динамических нагрузок. Широко применяемые в настоящее время высокотвердые керамики содержат большое число концентраторов напряжений (границ зерен, трещин, пор и т.д.), на которых активируется зарождение концентраторов разрушений даже в области упругого деформирования материала. Микроразрушения в таких материалах могут появиться при сжатии под действием девиаторных напряжений. С увеличением интенсивности импульса нагрузки степень микроразрушений в фазе сжатия резко возрастает, что приводит в последствии к падению сопротивления растяжению [1]. Повышенное внимание исследователей уделяется изучению функциональных свойств многокомпонентных металлокерамических материалов (слоистых, градиентных, наноструктурированных и др.) в условиях высокоэнергетического воздействия $[2,3]$ и поиска путей достижения необходимой ударной стойкости защитных конструкций.

Одним из перспективных методов повышения физикомеханических характеристик композиционных материалов для защитных преград является получение металлокерамических материалов с переменным составом, в том числе слоистого типа. Самораспространяющийся высокотемпературный синтез (СВС) с одновременным приложением давления к заготовке, содержащей экзо- термическую порошковую смесь, является надежным способом получения многокомпонентных, в том числе и слоистых материалов [4]. Разработанные СВС технологии и опережающий по научной и технической проработке зарубежные исследования задел $[5,6]$ позволяют быстро и эффективно решать проблему создания материалов нового поколения.

Целью настоящей работы является создание принципиально новых образцов комбинированных композиционных материалов для защитных конструкций от высокоскоростного удара за счет использования высокотвердой керамики в связке с интерметаллидом и высокопрочной металлической подложки.

\section{1. Разработка двуслойного металлокерамического материала}

Для ряда составов металлокерамик на основе диборида титана $\mathrm{TiB}_{2}$, карбида титана $\mathrm{TiC}$ и др. используется интерметаллид - никелид титана NiTi в качестве металлической связки, который обладает уникальными физико-механическими свойствами $[7,8]$. Сохранить такие свойства в металлокерамике после СВС и термосилового компактирования является сложной задачей.

В металлокерамике $\mathrm{TiB}_{2}+\mathrm{NiTi}$ основной фазой связки является NiTi, однако в процессе сложного влияния градиента температуры и деформации при синтезе формируются примесные фазы типа $\mathrm{Ni}_{4} \mathrm{Ti}_{3}$ и $\mathrm{Ni}_{3} \mathrm{Ti}_{2}$. Для исследования стабильности структурно-фазовых состояний и связанных с ними свойств плавленого объемного никелида титана при термосиловом воздействии проведена 


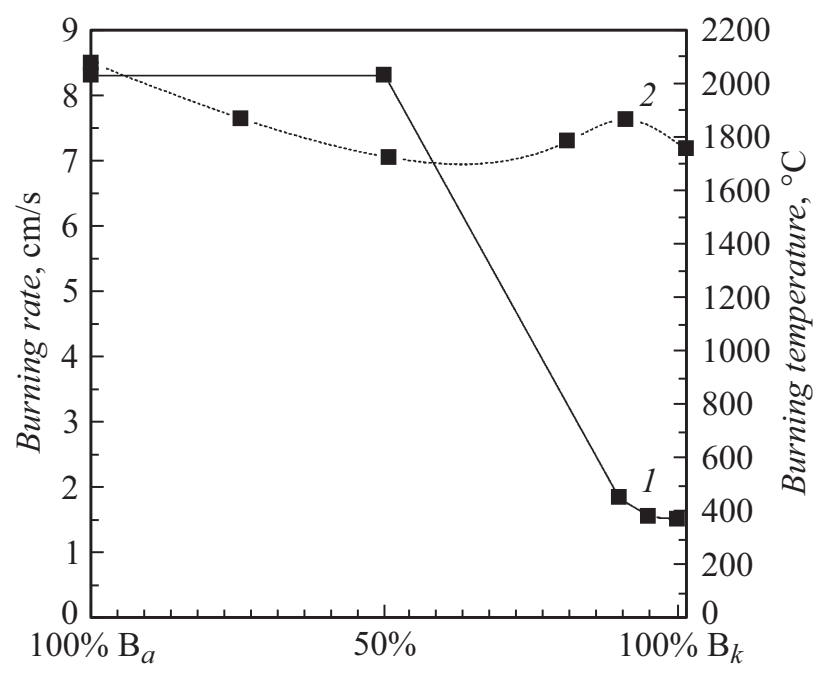

Рис. 1. Зависимость скорости (1) и температуры (2) горения от соотношения аморфного и поликристаллического бора в системе $\mathrm{TiB}_{2}+\mathrm{NiTi}$.

трехсторонняя $a, b, c$-деформация сплава в специальной прессформе на 100-тонном гидравлическом прессе со скоростью $4.6 \mathrm{~mm} / \mathrm{s}$. Исследованию подвергался сплав состава 50.2 Ni wt.\%+49.8Ti wt.\% $\left(\mathrm{Ni}_{50.2} \mathrm{Ti}_{49.8}\right)$, деформированный при ступенчатом понижении температуры в интервале $600-300^{\circ} \mathrm{C}$. Деформирование образцов на $662.7 \%$ при 600,400 и $300^{\circ} \mathrm{C}$ приводит к увеличению доли примесной фазы $\mathrm{Ni}_{4} \mathrm{Ti}_{3}$. С ростом деформации и ступенчатом понижении температуры в сплаве $\mathrm{Ni}_{50.2} \mathrm{Ti}_{49.8}$ происходит измельчение зерна от крупнозеренной до субмикрокристаллической. Обнаружен деформационный интервал, в котором сплав $\mathrm{Ni}_{50.2} \mathrm{Ti}_{49.8}$ проявляет повышенную циклостойкость. Добавочная холодная деформация приводит к смещению температуры фазовых переходов $\mathrm{Ni}_{50.2} \mathrm{Ti}_{49.8}$ и формированию мартенсита при комнатной температуре, что явилось основной причиной повышения устойчивости к циклическим нагрузкам. Повышение температуры испытания в интервале 5-90 ${ }^{\circ} \mathrm{C}$ приводит к повышению циклостойкости примерно на $40 \%$, что связано с совпадением температуры испытания и температурного интервала фазового перехода в $\mathrm{Ni}_{50.2} \mathrm{Ti}_{49.8}$. Полученные данные использованы для оптимизации конструирования металлокерамики на основе $\mathrm{TiB}_{2}$ со связкой $\mathrm{NiTi}$, эффективной в условиях высокоскоростного соударения.

Для получения двуслойного металлокерамического материала используется следующая композиция: лицевой слой - продукт экзотермической реакции системы $(\mathrm{Ti}+\mathrm{B}+\mathrm{Ni})$, полученной за счет приложения давления к разогретому СВС продукту, тыльный слой - инерт, роль которого играет титановый сплав Ті. Для управления параметрами горения (скоростью и температурой) экзотермических смесей порошков титана, бора и никеля при сохранении их количественного соотношения выбран способ регулирования среднего размера частиц бора, который осуществляется за счет смешивания двух марок порошков бора в соотношении $=a / k$, где $a-$ доля аморфного бора $\mathrm{B}_{a}$ с размером частиц до $1 \mu \mathrm{m}$, $k$ - доля поликристаллического бора $\mathrm{B}_{k}$ со средним размером частиц $\sim 53 \mu \mathrm{m}$.

На рис. 1 приведены зависимости скорости $U_{b u r n}$ и температуры $T$ горения в выбранных экзотермических смесях $\mathrm{TiB}_{2}+\mathrm{NiTi}$ от содержания $\mathrm{B}_{a}$ и $\mathrm{B}_{k}$ в смеси в процентах (слева содержание $\mathrm{B}_{a} 100 \%$, справа $-\mathrm{B}_{k}$ $100 \%)$. Видно, что скорость горения $U_{b u r n}$ выбранных (рис. 1, кривая 1) можно менять за счет дисперсности бора в несколько раз, в частности, от $8.3 \mathrm{~cm} / \mathrm{s}$ для смесей с аморфным бором $\mathrm{B}_{a}$ до $1.5 \mathrm{~cm} / \mathrm{s}$ с поликристаллическим $\mathrm{B}_{k}$. Причем изменение скорости горения от соотношения аморфного и поликристаллического бора имеет нелинейный характер. Температура горения в системе $\mathrm{TiB}_{2}+\mathrm{NiTi}$ меняется от 2100 до $1750^{\circ} \mathrm{C}$ и опи-
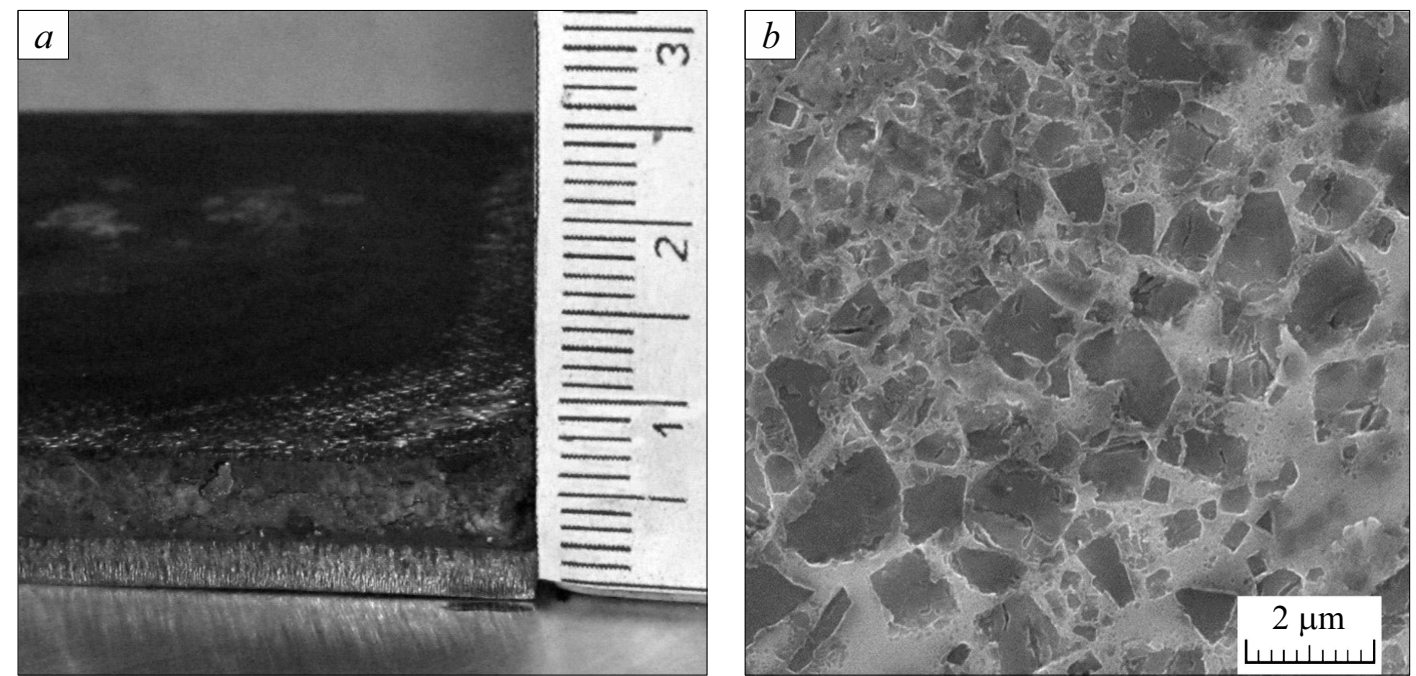

Рис. 2. Образец двуслойного металлокерамического материала $\left(\mathrm{TiB}_{2}+\mathrm{NiTi}\right)+\mathrm{Ti}: a-$ внешний вид, $b-$ микроструктура лицевого слоя. 

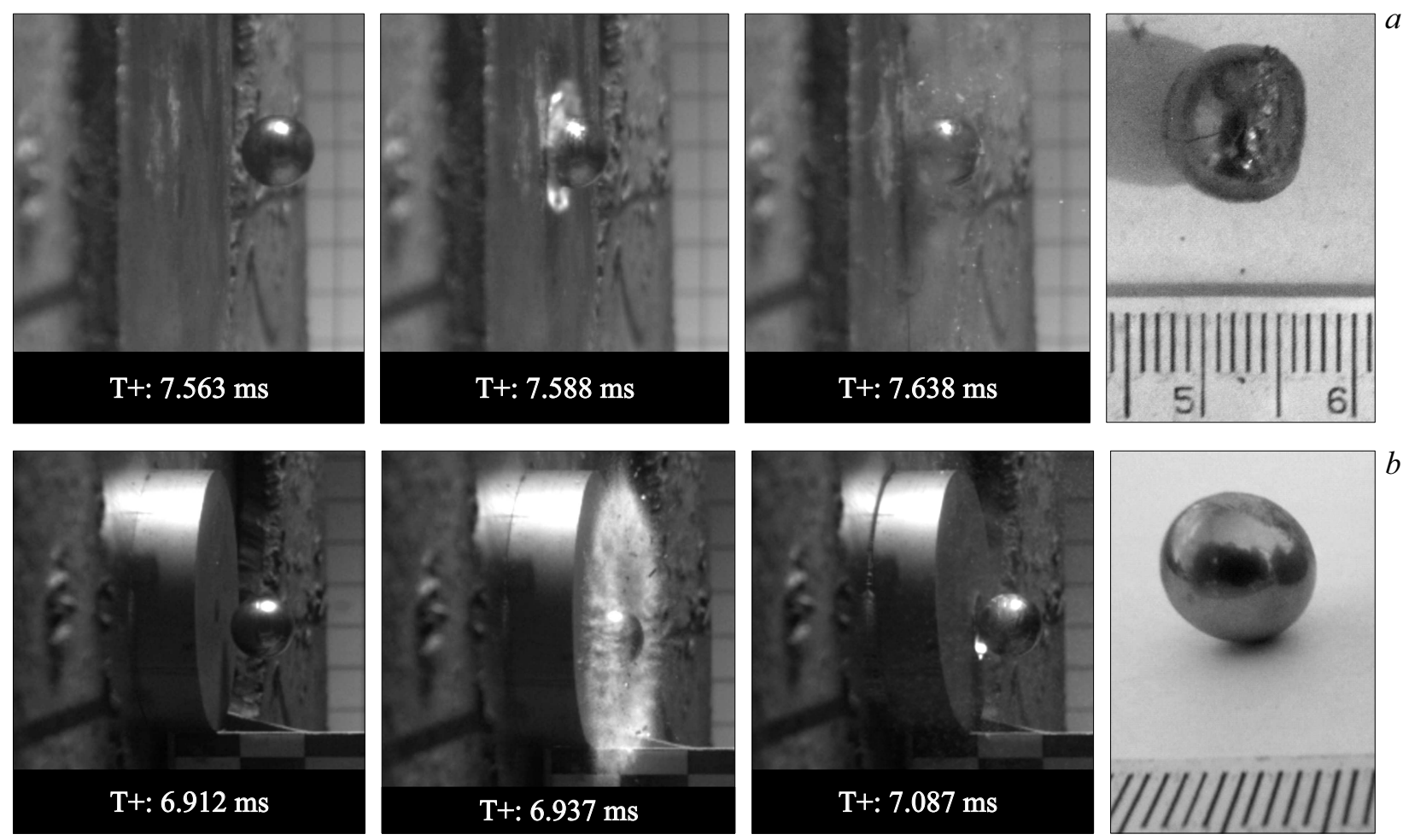

Рис. 3. Фоторегистограмма взаимодействия и вид сферического ударника после соударения с образцом двуслойного металлокерамического материала $\left(\mathrm{TiB}_{2}+\mathrm{NiTi}\right)+\mathrm{Ti}$ при $V_{0}=428 \mathrm{~m} / \mathrm{s}(a)$ и с эквивалентной титановой пластиной при $V_{0}=460 \mathrm{~m} / \mathrm{s}(b)$.
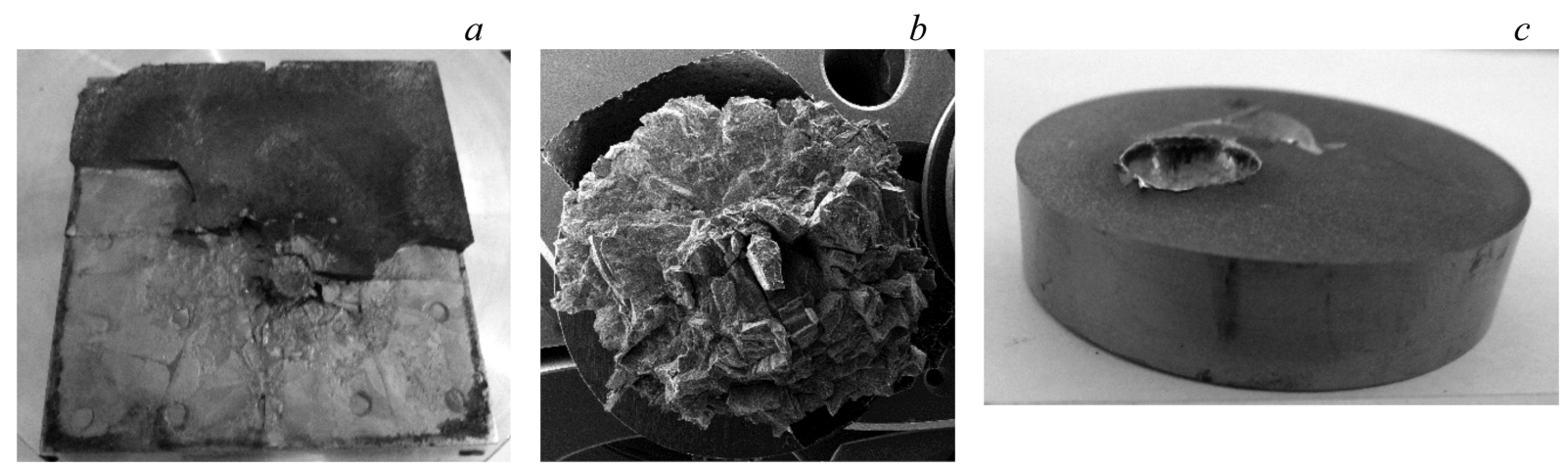

Рис. 4. Вид лицевой поверхности двуслойного металлокерамического материала $\left(\mathrm{TiB}_{2}+\mathrm{NiTi}\right)+\mathrm{Ti}(a)$, тыльной поверхности „пробки“ $(b)$ и эквивалентной титановой пластины $(c)$ после соударения.

сывается более слабой зависимостью от соотношения аморфного $\mathrm{B}_{a}$ и поликристаллического бора $\mathrm{B}_{k}$ (рис. 1, кривая 2).

Структура синтезированной металлокерамики $\mathrm{TiB}_{2}+\mathrm{NiTi}$ представляет собой смесь мелкокристаллических частиц $\mathrm{TiB}_{2}$ размером до $5 \mu \mathrm{m}$ и равномерно распределенной связующей фазы из NiTi. Bo всех случаях, кроме состава, содержащего только аморфный бор, дополнительно наблюдаются вкрапления отдельных более крупных кристаллов, максимальный размер которых достигает $150 \mu \mathrm{m}$. Количество таких кристаллов тем больше, чем выше доля поликристаллического бора в исходной смеси. Их микротвердость не зависит от соотношения аморфного и кристаллического бора в металлокерамике и составляет от 20 до $85 \mathrm{GPa}$. Микротвердость основной области, т.е. частиц $\mathrm{TiB}_{2}$ и связующей матрицы NiTi, составляет от 7.5 до $26 \mathrm{GPa}$.

Отличительной особенностью синтезированного металлокерамического материала $\mathrm{TiB}_{2}+\mathrm{NiTi}$ является повышенная трещиностойкость по сравнению с однофазными высокопрочными керамиками типа карбида бора, карбида кремния или оксида алюминия. Введение металлической связки делает материал более пластичным, вязким, препятствует росту трещин при сжатии и осо- 

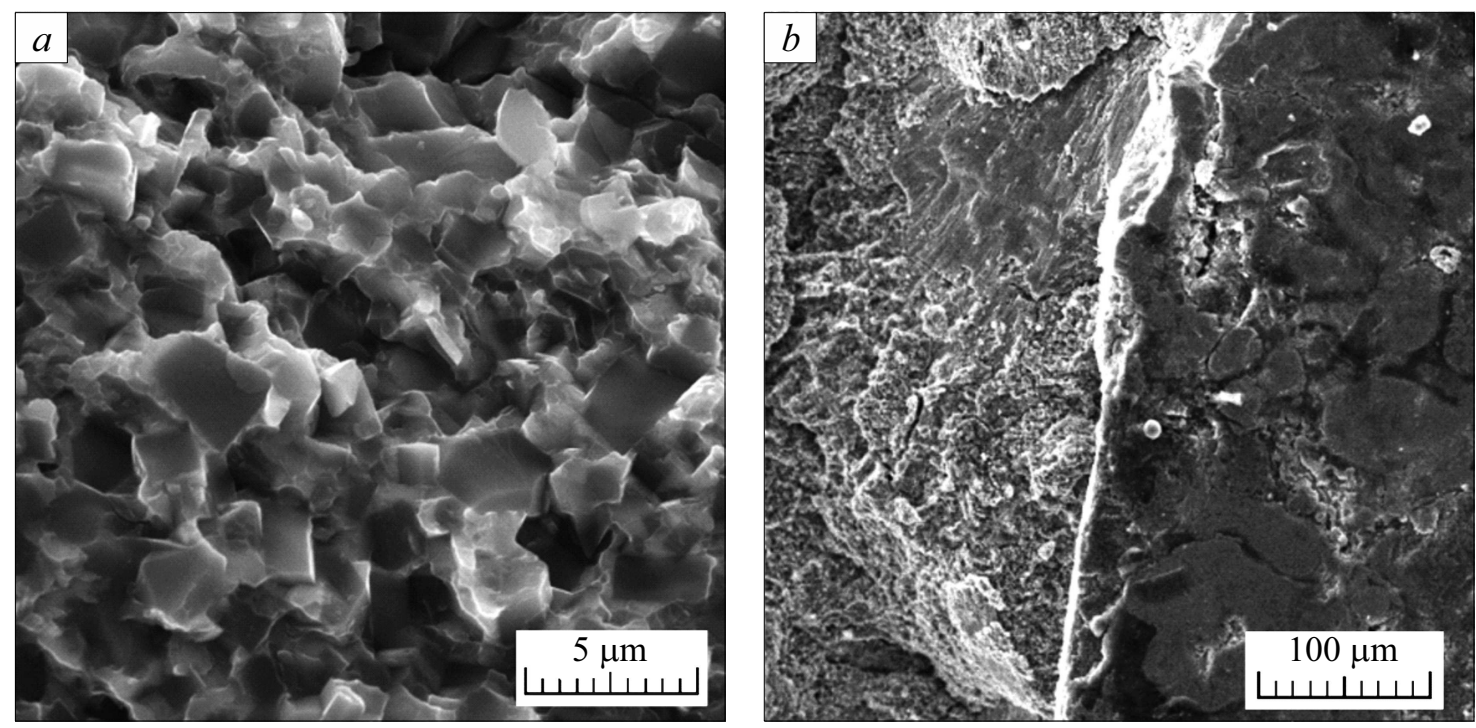

Рис. 5. Фрактограмма металлокерамического слоя двуслойного материала $\left(\mathrm{TiB}_{2}+\mathrm{NiTi}\right)+\mathrm{Ti}$ после соударения.

бенно растяжении, когда разрушение идет в основном по границам зерен. Вместе с тем уровень пластичности металлокерамики в целом незначителен и составляет несколько процентов.

Синтез двуслойного металлокерамического материала: лицевой слой металлокерамика $\mathrm{TiB}_{2}+\mathrm{NiTi}$, тыльный слой титан Тi - дополнительно приведет к демпфированию ударной нагрузки. На рис. 2 представлен вид полученного методом СВС с приложением давления к продукту синтеза образца двуслойного металлокерамического материала $\left(\mathrm{TiB}_{2}+\mathrm{NiTi}\right)+\mathrm{Ti}$ на основе экзотермической системы $\left(\mathrm{TiB}_{2}+\mathrm{NiTi}\right)$, расположенной на металлическом слое (Тi). Лицевой слой толщиной $4.7 \mathrm{~mm}-$ металлокерамика ( $\mathrm{TiB}_{2}+\mathrm{NiTi}$ ) плотностью $4.92 \mathrm{~g} / \mathrm{cm}^{3}$, тыльный слой толщиной $3 \mathrm{~mm}$ - титан марки ВТ1 плотностью $4.505 \mathrm{~g} / \mathrm{cm}^{3}$. Средняя плотность двуслойного металлокерамического материала $\left(\mathrm{TiB}_{2}+\mathrm{NiTi}\right)+\mathrm{Ti}$ составляет $4.73 \mathrm{~g} / \mathrm{cm}^{3}$. На (рис. $2, b$ ) представлена микроструктура металлокерамического слоя $\left(\mathrm{TiB}_{2}+\mathrm{NiTi}\right)$ : темные фрагменты - кристаллы диборида титана $\mathrm{TiB}_{2}$, светлые - связка из интерметаллида NiTi. Наблюдается равномерная мелкодисперсная структура материала с максимальным размером зерна не более $2 \mu \mathrm{m}$.

\section{2. Результаты \\ экспериментально-теоретических исследований противоударной стойкости двуслойного металлокерамического материала}

С целью определения противоударной стойкости пластины из двуслойного металлокерамического материала $\left(\mathrm{TiB}_{2}+\mathrm{NiTi}\right)+\mathrm{Ti}$ в сравнении с эквивалентной по поверхностной плотности пластиной из сплава ВТ1 толщиной $8.5 \mathrm{~mm}$ проведены испытания на экспериментальном баллистическом стенде [9]. Стальной термоупрочненный сферический ударник из стали ШХ-15 (твердость $70 \mathrm{HRC}$ ) диаметром $10 \mathrm{~mm}$ взаимодействует со скоростью $V_{0}$ с составной мишенью, содержащей образец исследуемого материала, расположенный на массивном диске из алюминиевого сплава Д16Т толщиной $7 \mathrm{~cm}$.

На рис. 3 представлены результаты экспериментов в виде фоторегистограмм: подлет ударника к преграде, соударение, обратное движение ударника после соударения, а также вид ударника после взаимодействия с защитной пластиной.

В результате удара при $V_{0}=428 \mathrm{~m} / \mathrm{s}$ (рис. $3, a$ ) лицевой слой металлокерамической пластины деформирован только в зоне удара, что при отскоке ударника иллюстрирует кадр, зарегистрированный при $7.638 \mathrm{~ms}$. Под контактной поверхностью с ударником в металлокерамике образуется фрагмент, отделенный от основного массива цилиндрической трещиной, - „пробка“ (рис. 4, $a, b$ ). В титановом слое комбинированного материала осталось незначительное углубление под „пробкой“ (к сожалению, в последующие моменты после соударения к преграде подлетели составные части метаемой сборки, которые не удалось предварительно отделить от ударника на траектории полета, и при их воздействии металлокерамический слой разрушился на фрагменты).

В ударнике после соударения (рис. 3,a) наблюдается пластическая деформация и трещинообразование: диаметр по оси движения уменьшился до $9.19 \mathrm{~mm}$, перпендикулярно оси движения увеличился до $10.28 \mathrm{~mm}$. Отскок ударника от преграды после соударения происходит со скоростью $-38 \mathrm{~m} / \mathrm{s}$, что составляет $8.9 \%$ от скорости удара. 


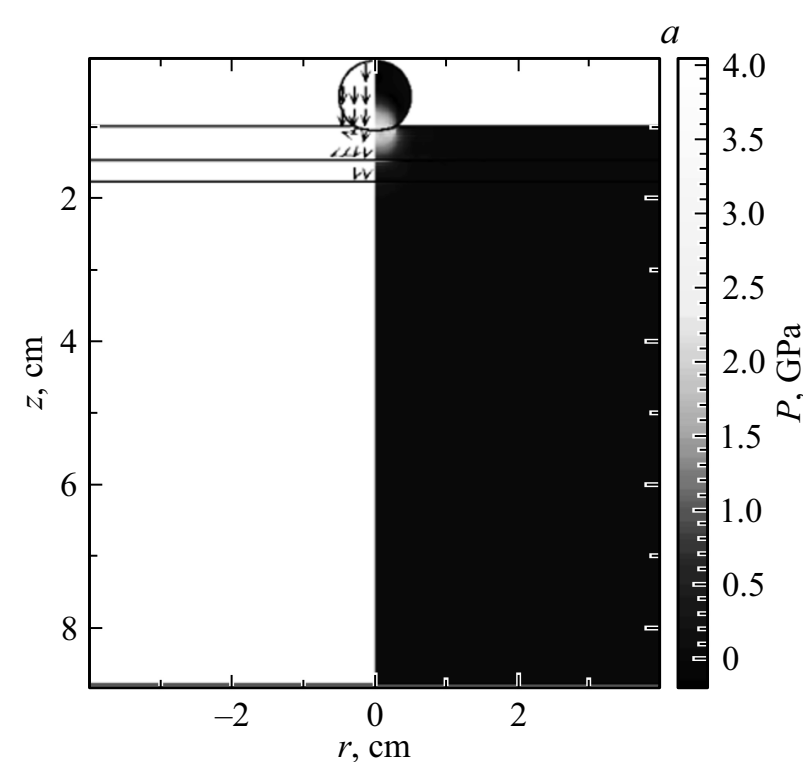

$c$
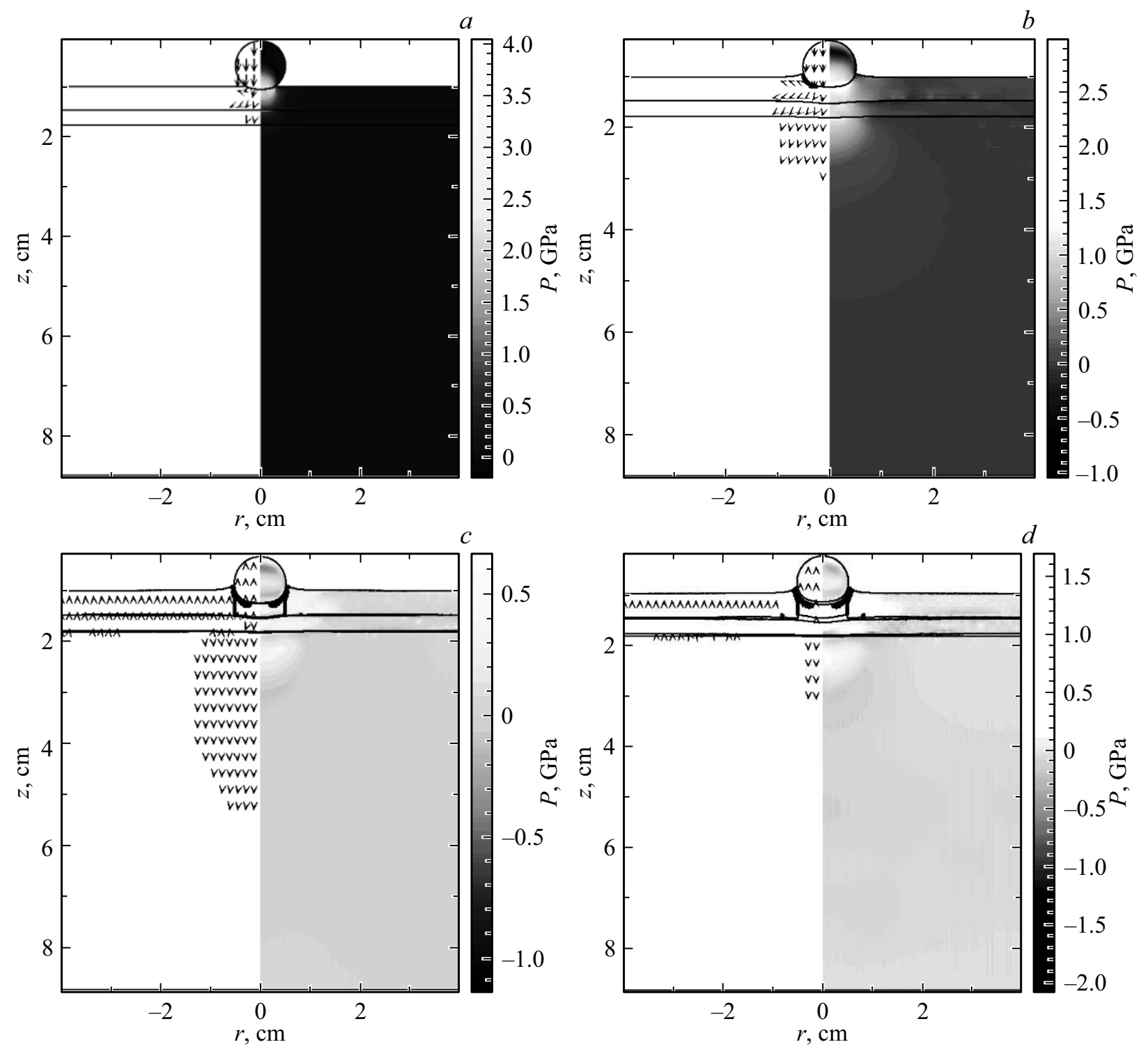

$d$

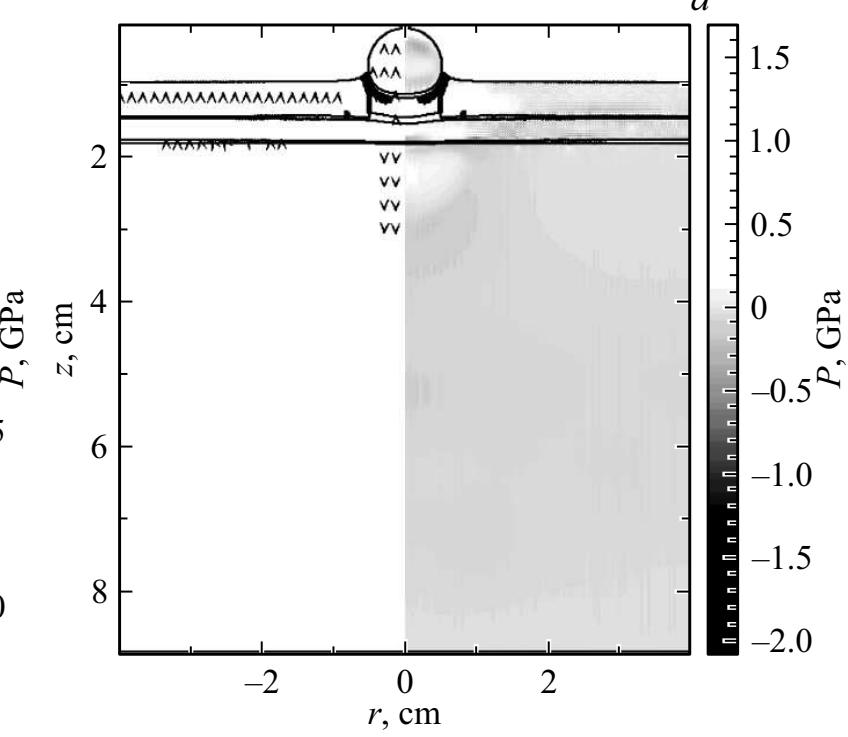

Рис. 6. Хронограмма взаимодействия стального сферического ударника с образцом двуслойного металлокерамического материала $\left(\mathrm{TiB}_{2}+\mathrm{NiTi}\right)+\mathrm{Ti}$, расположенным на дюралюминиевой подложке, при $V_{0}=428 \mathrm{~m} / \mathrm{s}: a-t=2 \mu \mathrm{s}, U_{\mathrm{max}}=422 \mathrm{~m} / \mathrm{s}, U_{\mathrm{cm}}=403 \mathrm{~m} / \mathrm{s}$, $P_{\min }=-0.19 \mathrm{GPa}, P_{\max }=4.05 \mathrm{GPa} ; b-t=8 \mu \mathrm{s}, U_{\max }=259 \mathrm{~m} / \mathrm{s}, U_{\mathrm{cm}}=241 \mathrm{~m} / \mathrm{s}, P_{\min }=-1.02 \mathrm{GPa}, P_{\max }=2.99 \mathrm{GPa} ; c-t=32 \mu \mathrm{s}$, $U_{\max }=64 \mathrm{~m} / \mathrm{s}, U_{\mathrm{cm}}=-60 \mathrm{~m} / \mathrm{s}, P_{\min }=-1.13 \mathrm{GPa}, P_{\max }=0.66 \mathrm{GPa} ; d-t=50 \mu \mathrm{s}, U_{\max }=74 \mathrm{~m} / \mathrm{s}, U_{\mathrm{cm}}=-61 \mathrm{~m} / \mathrm{s}, P_{\min }=-2.07 \mathrm{GPa}$, $P_{\max }=1.70 \mathrm{GPa}$.

При взаимодействии ударника с эквивалентной титановой пластиной (рис. $3, b$ ) при скорости $V_{0}=460 \mathrm{~m} / \mathrm{s}$ образуется кратер глубиной $4 \mathrm{~mm}$ (рис. 4,c). В этом случае наблюдается незначительная пластическая деформация ударника и отскок со скоростью $43 \mathrm{~m} / \mathrm{s}$, что составляет $9.3 \%$ от скорости удара.

Последнее обстоятельство говорит о большем расходовании кинетической энергии ударника при взаимодействии с двуслойным металлокерамическим материалом.

На рис. 5 представлена структура поверхности разрушения металлокерамического слоя $\left(\mathrm{TiB}_{2}+\mathrm{NiTi}\right)$ после соударения. Микроструктура (рис. 5,a) показывает равномерное распределение мелкокристаллических частиц
$\mathrm{TiB}_{2}$ в связующей фазе из NiTi. Причем размер зерна после соударения не увеличился и не превышает $2 \mu \mathrm{m}$, как и в невозмущенном материале. Отчетливо видно, что формирование трещин происходит по границе зерен, реализуя механизм зернограничного разрушения (рис. $5, b)$. Этот фактор обеспечивает повышенную трещиностойкость из-за введения металлической связки, препятствующей росту трещин при сжатии и растяжении. Вместе с тем металлический слой Ті дополнительно демпфирует ударную нагрузку на металлокерамический слой.

Условия описанного опыта повторены при математическом моделировании соударения с применением 
Параметры математической модели исследуемых материалов

\begin{tabular}{c|c|c|c|c|c|c|c|c|c|c}
\hline Материал & $\begin{array}{c}\rho_{m 0}, \\
\mathrm{~g} / \mathrm{cm}^{3}\end{array}$ & $\begin{array}{c}c_{m 0}, \\
\mathrm{~m} / \mathrm{s}\end{array}$ & $S_{m 0}$ & $\gamma_{m 0}$ & $\begin{array}{c}\mu_{m 0}, \\
\mathrm{GPa}\end{array}$ & $\begin{array}{l}\sigma_{m s}, \\
\mathrm{GPa}\end{array}$ & $\begin{array}{l}a_{s}, \\
\mathrm{GPa}\end{array}$ & $\alpha_{00}$ & $\alpha_{0}$ & $\chi^{*}$ \\
\hline Сталь & 7.85 & 457 & 1.49 & 2.0 & 79.0 & 1.0 & 0.43 & 1.0006 & 1.0006 & 0.3 \\
Титан & 4.51 & 478 & 1.088 & 1.33 & 48.0 & 0.6 & 0.42 & 1.0001 & 1.0001 & 0.3 \\
Д16Т & 2.78 & 539 & 1.284 & 2.1 & 27.7 & 0.26 & 0.27 & 1.0002 & 0.3 & 0.3 \\
$\mathrm{TiB}_{2}+\mathrm{NiTi}$ & 5.12 & 690 & 2.2 & 1.5 & 128.27 & 0.75 & 0.5006 & 1.0006 & 1.0822 & 0.1
\end{tabular}

При иечание. $\rho_{m 0}, c_{m 0}, S_{m 0}, \gamma_{m 0}, \mu_{m 0}, \sigma_{m s}$ - параметры матрицы материалов; $a_{s}, \alpha_{00}, \alpha_{0}, \varepsilon^{*}$ - параметры модели разрушения.

пористой упругопластической модели среды [2,10], параметры которой приведены в таблице. Расчет проведен с помощью программного комплекса [11].

Металлокерамика $\mathrm{TiB}_{2}+\mathrm{NiTi}$ моделируется гомогенной двуфазной смесью из $\mathrm{TiB}_{2}$ и $\mathrm{NiTi}$, начальная плотность матрицы которой $\rho_{m 0}$ определяется по формуле $\rho_{m 0}=v_{1} \rho_{01}+v_{2} \rho_{02}$, где $v_{1}, v_{2}, \rho_{01}, \rho_{02}-$ начальные объемные концентрации и плотности диборида титана и никелида титана соответственно. Другие параметры модели определены также по известным параметрам компонент. Предполагается, что материал может разрушаться по отрывному механизму, когда объем пустот достигает критического значения $\xi^{*}$, и по сдвиговому, когда удельная работа пластической деформации достигает критического значения $A^{*}$. Для расчета разрушения металлокерамики $A^{*}=0.5 \mathrm{GPa}$.

Результаты расчета (рис. 6) приведены в цилиндрической системе координат $r, z$ : в левой полуплоскости в виде распределения векторов массовой скорости относительно максимального значения $U_{\max }$, в правой полуплоскости в виде распределения давления, там же приведены максимальное $P_{\max }$ и минимальное $P_{\min }$ значения давления и скорость центра масс ударника $U_{\mathrm{cm}}$.

Процесс взаимодействия ударника и преграды характеризуется интенсивными нагрузками. В металлокерамическом слое на контактной поверхности с ударником материал сжимается, развивается зона разрушения (черный цвет), в последующие моменты формируется цилиндрическая трещина, отделяющая сжатый материал под ударником от растягивающегося к свободной поверхности материала. Этот фрагмент металлокерамики пробка, вдавливается в слой титана вместе с ударником.

Ударник пластически деформируется. В тыльной части ударника формируются условия для трещинообразования из-за возникающих растягивающих напряжений. К $16 \mu$ s ударник практически остановился в преграде, а в $32 \mu$ s уже движется в обратном направлении. К $50 \mu \mathrm{s}$ вектор массовой скорости в пробке приобретает обратное направление. В титановом слое под пробкой заметно углубление. К $8 \mu \mathrm{s}$ в дюралюминиевую подложку распространяются незначительные возмущения, которые к моменту отскока ударника практически затухают. Таким образом, титановый слой служит демпфером, ослабляющим ударную нагрузку.

\section{Заключение}

Методом СВС с приложением давления к продукту синтеза разработан двуслойный металлокерамический материал для защитных преград от высокоскоростного удара $\left(\mathrm{TiB}_{2}+\mathrm{NiTi}\right)+\mathrm{Ti}$. Лицевой слой материала представлен металлокерамикой на основе диборида титана со связкой из никилида титана, тыльный слой — титановым сплавом. Отличительной особенностью металлокерамического слоя является повышенная трещиностойкость из-за введения металлической связки, препятствующей росту трещин при сжатии и растяжении при реализации зернограничного разрушения. Тыльный слой из титанового сплава демпфирует ударную нагрузку, приходящуюся на металлокерамический слой при соударении.

По результатам анализа соударения стального сферического ударника с образцом $\left(\mathrm{TiB}_{2}+\mathrm{NiTi}\right)+\mathrm{Ti}$ в сравнении с эквивалентной однородной титановой пластиной можно сделать вывод о том, что, во-первых, наблюдается качественное различие в характере взаимодействия, выражающееся в отсутствии ударного кратера в металлокерамическом слое после соударения, во-вторых, двуслойный композиционный материал оказывает большое сопротивление прониканию стального ударника.

Математическое моделирование в рамках предложенной модели может применяться для прогнозных исследований противоударной стойкости разработанного двуслойного металлокерамического материала при различных условиях высокоскоростного соударения.

В настоящей работе использованы результаты, полученные в ходе выполнения проекта № 8.2.09.2018 Программы повышения конкурентоспособности ТГУ.

\section{Список литературы}

[1] Канель Г.И., Разоренов С.В., Уткин А.В., Фортов В.Е. Ударно-волновые явления в конденсированных средах. М.: Янус-К, 1996. 408 с.

[2] Белов Н.Н., Югов Н.Т., Абанасьева С.А., Табаченко А.Н., Коняев А.А., Толкачев В.Ф., Югов А.А. // ДАН. 2005. Т. 401. № 6. C. 165-173. [Belov N.N., Yugov N.T., Afanas'eva S.A. Tabachenko A.N., Konyaev A.A., Tolkachev V.F., Yugov A.A. // Doklady Akademii Nauk. 2005. Vol. 402. N 5. P. 617-622]. 
[3] Белов Н.Н., Югов Н.Т., Абанасьева С.А., Табаченко А.Н., Коняев А.А., Толкачев В.Ф., Югов А.А. // ТОХТ. 2005. T. 39. № 6. C. 107-119. doi: 10.1007/s11236-005-0126-0. [Belov N.N., Yugov N.T., Afanas'eva S.A. Tabachenko A.N., Konyaev A.A., Tolkachev V.F., Yugov A.A. // Theoretical Foundations of Chemical Engineering. 2005. Vol. 39. N 6. P. 622-627].

[4] Ищенко А.Н., Табаченко А.Н., Афбанасьева С.А., Белов Н.Н., Буркин В.В, Мариунова Л.С., Рогаев К.С., Югов Н.Т. // Изв. вузов. Физика. 2015. Т. 58. № 9. С. 131135.

[5] Новиков Н.П., Боровинская И.П., Мержсанов А.Г. // Процессы горения в химической технологии и металлургии. Черноголовка. 1975. С. 174-188.

[6] Табаченко А.Н., Крючкова Г.Г. // Инженерно-физический журнал НАН Беларуси. 1993. Т. 65. № 4. С. 492-495.

[7] Гюнтер В.Э., Дамбаев Г.Ц., Сысолятин П.Г., Зиганьшин Р.В., Темерханов Ф.Т., Поленичкин В.К., Миргазизов М.З., Пахоменко Г.С., Савченко П.А., Староха А.В., Федоров С.Д., Зубаиров Ф.С., Гиберт Б.К., Ходоренко В.Н., Кечеруков А.И., Ланшаков В.А., Ивченко О.А., Ясенчук Ю.Ф., Фомичев Н.Г., Зильберитейн Б.М., Итин В.И., Олесова В.Н., Борисова К.З., Благитко Е.М., Левенеи, А.А., Плоткин Г.Л., Оскретков В.И., Звигинцев М.А., Илюшенов В.Н., Старосветский С.И., Дуров М.Ф., Петров Л.Н., Анисеня И.И., Новиков В.А., Оленников М.К., Ким Д.С., Веронский Г.И., Радионченко А.А., Штобин С.Г., Тазин И.Д., Запускалов И.В., Логвинов С.В., Махнев А.В., Медведев Ю.А., Тарабарин С.А., Водянов Н.М., Филюрин М.Д., Пушкарев В.П., Мельник Д.Д., Чернявский И.Я., Кричевский А.Л., Масликов В.М., Михайлов В.Д., Ильин А.А., Еременко А.И., Коломейцев П.И., Горячев А.Н., Цодекс В.М., Давыдов В.А., Савиных В.И., Кошкин Г.А., Гоппе В.И., Ардашев И.П., Исламгалиев Х.Н., Мезенцев Г.Д., Демиденко В.С., Наумов И.И., Нартайлаков М.А., Алиев Ф.Ш., Оленникова М.М., Берман А.М., Клопотов А.А., Машкин А.М., Мартынов С.А., Куценко И.Г., Вусик А.Н., Крючков И.М., Дамбаева Е.Г., Загребин Л.В., Мысливцев С.В., Радкевич А.А., Иванов А.Н., Исаенко В.И., Оспанов О.Б., Проскурин А.В., Шеметов В.П., Гошкадеря А.В., Сергеев К.С., Соловьев М.М., Соколович Е.Г., Гарафутдинов Д.М., Черненко С.В., Шустова В.А., Кожевников А.М., Коврижных В.В., Шакиров А.Н., Плотников В.В., Мухамедов М.Р., Якушенко В.К., Сысолятин С.П., Потехин В.К., Ручкин В.И., Кононов В.П., Корнилов Б.М., Рождественский С.В., Шкуратов С.И., Терлеикая Е.Н., Байдина Т.Ф., Белочерковский И.А., Васильев А.В., Ивченко А.О., Молчанов Н.А., Иванов П.В., Малеткина Т.Ю., Чаторов Е.В., Дудин М.А., Лобатый А.П., Стеблюк А.Н., Вольфовский В.З., Лазарев В.Я., Бисюков Д.А., Смолин С.М., Бородин В.В., Меликян М.Л., Панов Л.А., Кири В.А., Светышева Ж.А., Сытин Л.В., Кочкин В.В., Петелин В.Л., Миндлин А.Е., Юдин П.С., Бородин Н.А., Высочкин В.П., Афбонин В.Я., Трищенков Н.Н., Фефелов А.В., Казанцев А.Б., Березовская А.А., Семухина Н.Г. Медицинские материалы и имплантаты с памятью формы. Томск: Изд-во Том. ун-та, 1998. 488 с.

[8] Otsuka K., Ken X. // Progr. Mater. Sci. 2005. Vol. 50. P. 511678.
[9] Бураков В.А., Буркин В.В., Ищенко А.Н., Корольков Л.В., Степанов Е.Ю., Чупашев А.В., Агафонов С.В., Рогаeв К.C. / Патент на изобретение № 2591132 от 20 июня 2016 г.

[10] Белов Н.Н., Демидов В.Н., Ефремова Л.В., Жуков А.В., Николаев А.П., Симоненко В.Г., Трушков В.Г., Хабибуллин М.В., Шиповский И.Е., Шуталев В.Б. // Изв. вузов. Физика. 1992. № 8. С. 5-48.

[11] Хабибуллин М.В., АЯанасьева С.А. Расчет явлений, происходящих в конденсированных средах в результате интенсивных импульсных воздействий, в осесимметричной постановке / Федеральная служба по интеллектуальной собственности, патентам и товарным знакам. Свидетельство о гос. регистрации программ для ЭВМ № 2012617301. M. 2012. 